Volume and Issues Obtainable at Center for Sustainability Research and Consultancy

Journal of Accounting and Finance in Emerging Economies

ISSN: 2519-0318 \& ISSN (E): 2518-8488

Volume 7: Issue 4 December 2021

Journal homepage: www.publishing.globalcsrc.org/jafee

\title{
What Factors Drive the Banks Systemic Risk among South Asian Countries?
}

Raheel Mumtaz, College of Commerce, Government College University, Faisalabad, Pakistan.

Quaisar Ijaz Khan, College of Commerce, Government College University, Faisalabad,

Pakistan.

*M. Farooq Rehan, College of Commerce, Government College University, Faisalabad,

Pakistan.

*Corresponding author's email: farooq.rehan@gcuf.edu.pk

\begin{tabular}{l}
\hline ARTICLE DETAILS \\
\hline History \\
Revised format: Nov 2021 \\
Available Online: Dec 2021 \\
\hline
\end{tabular}

Keywords

Bank Systemic Risk, Bank

Size, Leverage, Liquidity, Interest Income

\section{JEL Classification}

G20, G21

\section{ABSTRACT}

Purpose: This study designs to examine the determinants (size, liquidity ratio, leverage ratio, deposit ratio, asset growth, net interest income ratio and return on asset ratio) of bank's systemic risk. We use the data of listed commercial banks of the South Asian countries (Pakistan, Bangladesh, and India).

Design/Methodology/Approach: The sample consists 30 banks from Bangladesh, 87 banks from India and 22 banks from Pakistan. This study covers the period from 2006 to 2018. The data is collected from the published annual reports of banks and stock exchanges of respective country. The panel data analysis is performed for the estimation of research models.

Findings: The findings demonstrate that larger banks contribute lower in the systemic risk of banks. Additionally, highly liquid banks enhance the systemic risk of the banking system. Moreover, the banks with greater reliance on the deposits, net interest income and with high return on asset reduce the systemic risk contribution of the banks.

Implications/Originality/Value: This study provides the justification to devise the banking policies like enhance the proportion of liquidity among assets, reliance on net interest income and promote the financing needs through deposits to limit the systemic risk contribution of the banking system.

(C) 2021, The authors, under a Creative Commons AttributionNonCommercial 4.0

Recommended citation: Mumtaz, R., Khan, Q. I. and Rehan, F. (2021). What Factors Drive the Banks Systemic Risk among South Asian Countries? Journal of Accounting and Finance in Emerging Economies, 7 (4), 823-831.

\section{Introduction}

Recent financial crisis develops the interest to study the phenomena of bank's systemic risk. Systemic risk is a situation when the failure of banks or financial institutions and its intermediaries have effect on entire banking system or financial institutions due to interconnections of these banking systems/financial institutions and financial intermediaries. The 
failure of banking system, financial institutions, and financial intermediaries take on to financial distress on financial institutions which give money to it, this leads to distress to some financial institutions. This leads to spillover effect across financial institutions and intermediaries across countries (Dash 2019).

The subsequent Euro-zone crises (2010-11) and the global financial crises (2008-09) getting attention of regulators and policy makers to find out the measures of systemic risk in banking system. The various financial organizations need to considerate those elements which are contributing to systemic risk. The breakdown of the absolute most unmistakable banks on the world, including the Washington Mutual and Lehman Brothers Bank, alongside a few close failures which must be rescued of emergency by the Government of U.S., featured the essentialness of getting, estimating, and observing systemic risk (Oanea et al 2016).

The many financial institutions and its intermediary have gone failure due to the global financial crises. These crises have a direct effect on banking sectors due to this effect many banking sectors of the world gone bankruptcies. The bank faced slow down economic growth in the form of systemic risk. The failures of banks awake the significance of systemic risk to monitor and supervise the factors which affect the systemic risk. With the development of networking technology in banking sectors and interlinked financial institutions across the countries to increase the risk spillover across the countries (Adrian and Brunnermeier, 2016).

Business analysts have recommended that undercapitalization of huge financial organizations can bring about budgetary shakiness, especially when the whole monetary organizations is undercapitalized. This is prompts the idea of "too interconnected to fail" (TICTF), for example that financial organizations that are profoundly between associated with different institutions are fundamentally significant thus can't be permitted to fail. A comparative idea is that of "too big to fail" (TBTF), for example that big financial organizations are so fundamentally significant that they can't be permitted to fail.

An inquiry that few researchers have presented is: which money related organizations ought to be bailed out in case of a dissolvability/liquidity crisis (Acharya et al 2012)? This sensibly requires distinguishing which organizations are basic to strength of the financial framework, for example "systemically significant." The Basel Committee on Banking Supervision (BCBS), demonstrate the idea of systemic significance ought to be estimated as far as the potential effect of the failure of a bank on the worldwide monetary framework and more extensive economy, as opposed to simply the risk that a failure can happen (Zhou 2014).

The various hypotheses are recommending that enormous and complex banks add to systemic risk. A potential pulls for the fundamental significance of huge, between associated banks is good peril; as controllers are reluctant to shut or slacken down immense and complex banks, this leads banks to go out over the top chance the longing for government bailouts (Tirole 2012). Another plausibility is that of agency effects, for example that poor administration of big and complex banks can prompt bank administrators taking part in non-traditional risky activities (for instance, exchanging) and will in general be financed increasingly through momentary obligation, making them progressively helpless against liquidity stuns and market failures (Ratnovski, 2012).

This study uses the data of commercial banks of the South Asian countries (Pakistan, Bangladesh, and India). The selected countries' central banks make policies to formulate and regularize the smooth functions of respective countries scheduled commercial banks. Banks of these countries consist of foreign banks, private banks, co-operative bank and Commercial banks provide multiple services. In Bangladesh, four nationalized banks operate their businesses, thirtynine commercial and private banks perform their services. In Pakistan, seven nationalized banks 
perform their services. In India, twenty-seven nationalized banks have run their business to facilitate the buainess.

This study examines the determinants of bank systemic risk using panel data analysis. The same studies developed for developing countries to determine their effect on bank systemic risk. The rest of the paper organize as follows section 2 describes literature review, section 3 methodology, section 4 result \& discussion and section 5 conclude the discussion.

\section{Literature Review}

There are numerous studies which have been proposed for the measurement of systemic risk. The measurement of systemic risk in previous studies represents as follows. Galati and Moessner (2013) explained that there is no consensus on systemic risk definition despite the plethora of research on the subject matter. Biasis (2012) stated that the focus on different phenomena like imbalances, the negative effect on the economy, information asymmetry, effects of feedback, contagion, asset bubbles, and negative externalities collapse in confidence, financial institutions' exposures correlated in nature.

The systemic risk indicates a dire need for generally accepted measures and well-defined principles for measuring it. Due to complex nature of systemic risk and lack of consensus in the literature regarding definition. Financial analysts are attempting to issue suitable observational measures to more readily ascertain the systemic risk measures as they think about the broadly utilized ones, the Beta and the Value at Risk, weren't proficient to manage the worldwide virus as commandingly exhibited by the ongoing monetary emergency (Danielsson et al., 2011).

The systemic risk related literature consists of the theoretical models that scrutinize specific aspects and evaluate of the systemic risk. It consists of the empirical analyses of the historical events, which are considered as the financial crisis. The standard Merton model develops for the financial system monitoring, proposed by some researchers (Lehar 2005). The data availability one of the crucial inadequacies to systemic risk measures. However, researchers develop to manage fine indicators of fragility. Few studies like Elsinger et al. (2006) and Gauthier et al. (2012), used network analysis in order to detect the level of distress exerted on financial institutions, for the British and Canadian Banks and inter markets. Their analysis relies more on the existing linkages between the agents.

Another methodology estimates systemic risk commitment in a manner that takes the free information of securities exchange come back to measures the commitments of the fundamental danger of each money related establishments. The instances of these methodologies Marginal Expected Shortfall (MES) and Systemic Expected Shortfall (SES). These methodologies estimate the foundational chance commitments use securities exchange return information. The (MES) approach creates by Acharya (2017) and (SES) approach creates by Pedersen, Philippon, and Richardson (2010).

The calculation of the systemic risk contribution of financial institutions a few other authors used Credit Default Swaps (CDS). Furthermore, Segoviano and Goodhart (2009) using the CDS data constructed a stability index to measure interdependence of financial institutions. This restricts researchers to use this measure to recognize systemic risk contribution of various financial institutions within the economy due to non-accessibility of information. Also, Acharya, Pederson, Philippon, and Richardson (2017) to gauge the systemic risk commitment of budgetary establishments proposed Systemic Expected Shortfall (SES) and Marginal Expected Shortfall (MES). During the seasons of monetary related misery, they quantified the foundational chance commitment of a monetary organization. 
The measures of the Systemic Expected Shortfall (SES) and Marginal Expected Shortfall (MES) use financial institutions equity returns. The marginal expected shortfall (MES) is the loss of the financial institution that is average in nature and the Systemic Expected Shortfall (SES) is the weighted average of the leverage and MES (Acharya et al, 2017). However, Brownlees and Engle (2011) for computations of time-varying systemic risk used the bivariate model of GARCH and the non-parametric estimator. Schwab, Koopmans, and Lucas (2010) for measurement of systemic risk proposed a framework. They develop indicator for large number of financial institutions. Due to access to the credit and unobserved changes in the supply, the credit risk conditions can separate from the fundamentals and disconnect. These conditions will increase the financial distress and leads the financial instability of the system. Acharya proposed the SRISK measures, Engle and Richardson (2012) and Brownlees and Engle (2012) use the Marginal Expected Shortfall (MES). Marginal Expected Shortfall (MES) measure considers the size of financial institution and structure of liabilities.

Data of Romanian banks show that financial leverage, market to book value, size and risk was positively affecting the contribution of systemic risk (Oanea et al., 2016). They employed ( $\triangle \mathrm{CoVar}$ ) systemic risk contribution approach. In Europe, banks systemic risk, size and leverage positively contribute to systemic risk (Bori et al., 2012). Hautsch et al (2014) deployed the ( $\triangle \mathrm{CoVar}$ ) approach and used the data of European banks, they found that unlike funding risk and leverage, bank size is dominant factor of systemic risk. Vallascas and Keasey (2012) use the data of European banks, result shows that size, leverage, and liquidity determine the bank systemic risk. The businesses, loans to individuals and other organizations, as well as securities that it owns are the major assets of banks. The depositors, shareholders, and money that are borrowed from other banks bank are able to obtain such assets due to capital. Bank generates income cannot use all of its assets. The cash must be available for customers from required reserves; because of leverage, a bank's return on equity is typically much higher than their return on assets. Leverage is the concept of increase possible return on investment using borrowed funds. Systemic risk logically increases as return on assets decreases like it did prior to and during the financial crisis Jeffrey Mills (2018).

\section{Methodology}

This study deploys the panel data of banks in three South Asian countries namely Bangladesh, India, and Pakistan. This study covers the period from 2006 to 2018. The study examines each country's banks on the country level. The study uses bank-level determinants (size, leverage ratio, liquidity ratio, assets growth, deposit ratio, and net interest income ratio) to examine the risk contribution in systemic risk. The sample selection consider countries which are ruled by two hundred years under the British ruler. The central bank makes policies to formulate and regularize the smooth functions of banks in respective countries. Banks of countries have foreign banks, private banks, cooperative bank commercial these banks provide different services. The same studies develop for developing countries to determine their effect on bank systemic risk.

\section{Data}

This study explores the determinants of bank systemic risk. The study determines to scrutinize the potential determinants of systemic risk in banking sector. The study selects these countries because are countries have similar in the banking mode of transaction due to cultural similarities among these countries. The study aims to develop to determine whether the factors that are affecting the bank's systemic risk are the same among the South Asian countries. The population consists of all countries of South Asia and data is collected from Stock exchanges of each country, i.e. Pakistan, India, Bangladesh. The sample contains 30 banks from Bangladesh, 87 banks from India and 22 banks from Pakistan. The stock prices and bank-level data is collected from PSX (Pakistan stock trade) and websites of all listed commercial banks. Indian information of stock prices is extracted from NSE (National stock trade) and Bombay stock exchange for 
listed commercial banks data get from these Indian stock exchanges. Same as for Bangladesh stock price data is collected from DSE (Dhaka stock exchange) and Chittagong stock exchange. The Bangladesh stock prices data is extracted from both stock exchanges. This study uses other sites for collection of data like Bloomberg, Wall street journal, and Business recorder.

Data sources

\begin{tabular}{|l|l|c|}
\hline Countries & Stock Exchange/s & Number of Listed Banks \\
\hline Pakistan & Pakistan Stock Exchange & 22 \\
\hline India & National Stock Exchange & 87 \\
\hline Bangladesh & Dhaka Stock Exchange & 30 \\
\hline
\end{tabular}

\section{Measurement of Variables}

We use the Marginal Expected Shortfall (MES) to measure the bank systemic risk. The marginal expected shortfall (MES) proxy is developed by Acharya et al (2017). It is the situation when the whole market goes down in a specific period. The Marginal expected shortfall (MES) during this time period the worst 5\% days' contribution to systemic risk Acharya et al (2013). Size measures as the log of total assets (Smirlock, 1985). Return on assets measures as net profit after tax over total asset (Matar 2003). The liquidity ratio used in this study measure as liquid assets over total assets. The higher liquidity ratio showing that more short lived assets of a bank. Liquidity ratio measures as securities over total assets (Anbar et al 2011). Bank major sources for funds deposits considered an important part (Anbar et al 2011). Deposit ratio calculates as banks deposit over total assets. Net income calculated as net profit over total fund (Dash, 2019). Leverage ratio measures as total assets over total common equity. Asset growth measures as quarterly total asset return \% (Zhao et al 2018).

The Study explores the determinants (size, leverage ratio, liquidity ratio, and deposit ratio, return on assets ratio, net interest income ratio, and assets growth) on bank systemic risk use panel regression. In this case, the research model of systemic risk writes as follows.

Systemic Risk $(\mathrm{MES})_{\mathrm{it}}=\alpha_{0}+\alpha_{1}(\mathrm{SZE})_{\mathrm{it}}+\alpha_{2}(\mathrm{LEV})_{\mathrm{it}}+\alpha_{3}(\mathrm{ROA})_{\mathrm{it}}+\alpha_{4}(\mathrm{AG})_{\mathrm{it}}+\alpha_{5}(\mathrm{LIQ})_{\mathrm{it}}+\alpha_{6}(\mathrm{NII})_{\mathrm{it}}$ $+\alpha_{7}(\mathrm{DR})_{\mathrm{it}}+\mathrm{i}_{\mathrm{t}}$

Where $_{\text {It }}=$ in period $\mathrm{t}, \alpha=$ Constant term, it $=$ Random error term, MES $=$ Marginal Expected Shortfall, SIZE $=$ Log of total assets, $\mathrm{LEV}=$ Leverage Ratio, ROA= Return on Assets, AG= Assets Growth, LIQ= Liquidity Ratio, NII= Net Interest Income Ratio, DR= Deposit Ratio, $(\mathrm{MES})_{\text {it }}=$ MES use as a concentrate subordinate variable as intermediary of foundational chance. MES estimates when the general market is in the tail of its misfortune appropriation the normal firm return on $5 \%$ most noticeably terrible days. Size = size measures as a log of total assets, $\mathrm{LEV}_{\text {it }}=$ Leverage is a measure of total assets over total equity, ROA $\mathrm{it}=$ Return on assets (ROA) measures as net income over total assets. $\mathrm{AG}_{\mathrm{it}}=$ Asset growth is a measure to be given through the quarterly return on total assets.LIQ it $=$ Liquidity measures as securities available for sale over total assetsNII $\mathrm{it}_{\mathrm{it}}=$ Net interest income measures as net profit over total fundsDR $\mathrm{it}_{\mathrm{it}}=$ Deposit ratio measures as a total deposit over total assets.

\section{Findings}

This study is designed to identify the factors which influence the systemic risk of banking system in south Asian countries. We determine the extent by which few banks contribute less and other contribute high in the financial system risk. Descriptive statistics, correlation matrix and regression analysis are used to examine the results of this study.

\section{Descriptive Statistics and Correlation Matrix}

Table 1 shows the descriptive statistics for all countries namely Bangladesh, India, and Pakistan and covers the period from 2006 to 2018. It reports the summary of variables (percentile points, mean, median and standard deviation) which are deployed to estimate the linear models in the regression results section. 
MES has a mean value of -0.0307 which shows that banks on average contributes to the financial system risk. The explanatory variables of the study are size, liquidity ratio, leverage ratio, asset growth, return on assets, deposit ratio, and net interest income ratio. Figure 1 explains the detailed risk contribution of on average banks in their respective country financial system risk. All countries banks contribute more to the financial system risk during the financial crisis of 2007-09. Later on, all countries central banks may take corrective action to reduce the risk contribution of individual banks to a whole financial system.

Table 1: Descriptive Analysis

\begin{tabular}{llllllll}
\hline & P01 & P25 & Mean & Median & P75 & P99 & Stdev \\
\hline MES & -0.0815 & -0.0423 & -0.0307 & -0.0295 & -0.0195 & 0.0023 & 0.0176 \\
Size & 16.6181 & 19.1861 & 20.9527 & 20.3030 & 21.9607 & 26.7221 & 2.6462 \\
Liq & 0.0093 & 0.0726 & 0.1109 & 0.0957 & 0.1374 & 0.3209 & 0.0623 \\
Lev & 0.0000 & 11.3470 & 15.0640 & 14.8493 & 18.2825 & 49.1744 & 7.2162 \\
AG & -2.1971 & -0.6771 & -0.1517 & 0.0090 & 0.2368 & 1.8871 & 0.8736 \\
ROA & -0.0615 & 0.0039 & 0.0068 & 0.0082 & 0.0129 & 0.0425 & 0.0157 \\
DR & 0.1146 & 0.7371 & 0.7727 & 0.8078 & 0.8569 & 0.9110 & 0.1360 \\
II & 0.0832 & 0.6447 & 0.7260 & 0.7686 & 0.8787 & 0.9462 & 0.3261 \\
NII & 0.0538 & 0.1213 & 0.2740 & 0.2314 & 0.3553 & 0.9168 & 0.3261 \\
D_I & 0.0000 & 0.0000 & 0.4372 & 0.0000 & 1.0000 & 1.0000 & 0.4965 \\
D_B & 0.0000 & 0.0000 & 0.1381 & 0.0000 & 0.0000 & 1.0000 & 0.3453 \\
\hline
\end{tabular}

MES is Marginal Expected Shortfall, size is natural log of bank size, Liq is liquidity ratio, Lev is leverage ratio, AG is assets growth, ROA is the return on assets ratio, DR is deposit ratio, and II is interest income ratio.

Table 2 reports the correlation coefficient of the systemic risk. It is positively correlated with size leverage, return on assets and interest income. Furthermore, systemic risk is negatively correlated with liquidity, assets growth, and deposit ratio. Explanatory variables have small correlation values which indicate that there is little/no problem of multicollinearity.

Figure 1. Bank's Average Risk Contribution in their Banking System

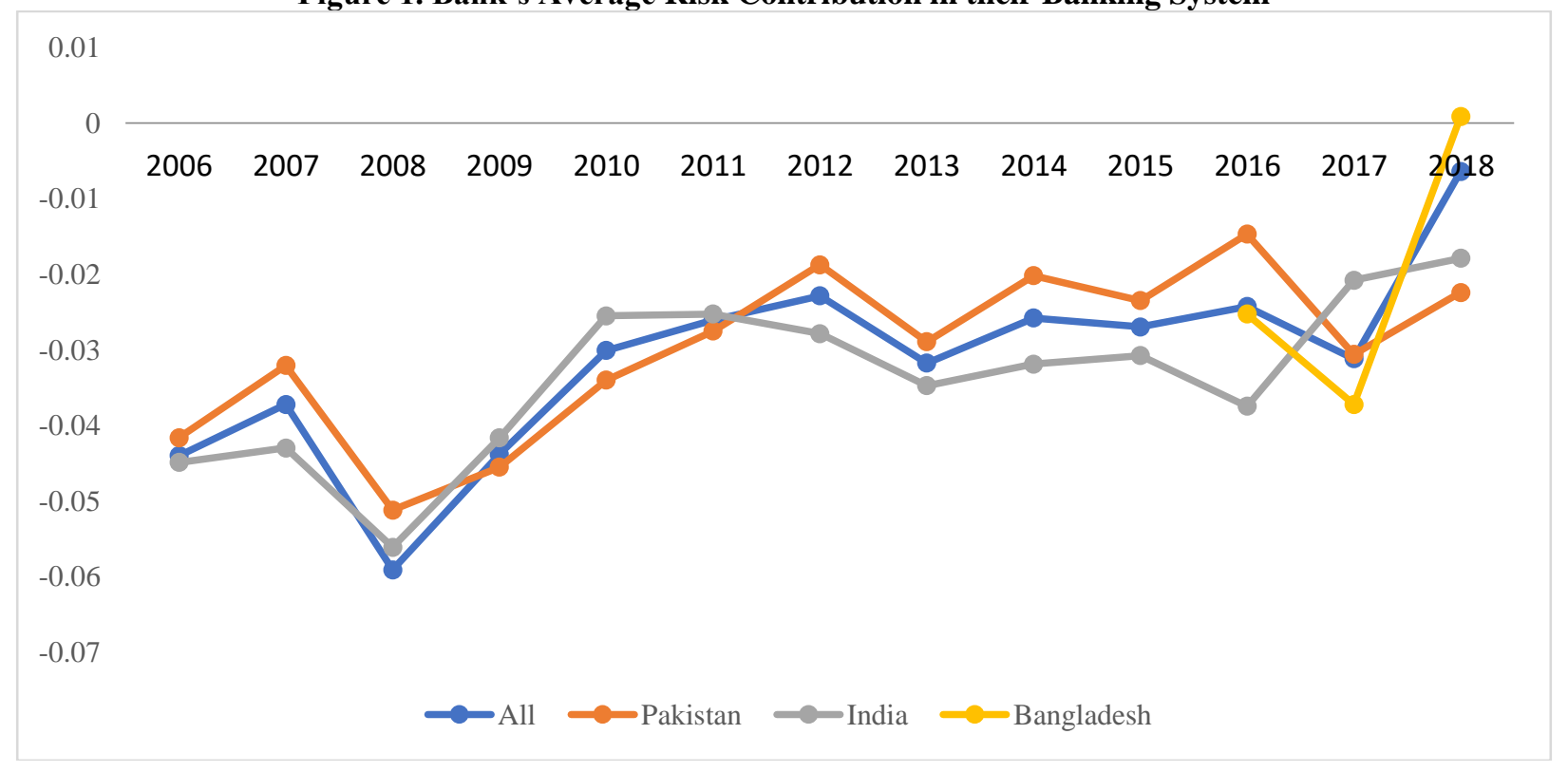


Table 2. Correlation Matrix

\begin{tabular}{|c|c|c|c|c|c|c|c|c|c|c|}
\hline & MES & Size & Liq & Lev & AG & ROA & DR & II & D_I & D_B \\
\hline MES & 1 & & & & & & & & & \\
\hline Size & 0.2316 & 1 & & & & & & & & \\
\hline Liq & -0.1485 & -0.1288 & 1 & & & & & & & \\
\hline Lev & 0.0044 & 0.0360 & -0.1055 & 1 & & & & & & \\
\hline $\mathbf{A G}$ & -0.1256 & -0.1448 & 0.0598 & -0.1120 & 1 & & & & & \\
\hline ROA & 0.1142 & 0.1473 & -0.0914 & -0.2701 & 0.1555 & 1 & & & & \\
\hline DR & -0.0300 & -0.1860 & -0.1392 & 0.2792 & 0.0024 & -0.1239 & 1 & & & \\
\hline II & 0.0605 & -0.0880 & -0.1344 & -0.0223 & -0.0302 & 0.1815 & 0.2183 & 1 & & \\
\hline D_I & -0.0789 & -0.0277 & -0.4381 & 0.0829 & -0.0347 & 0.0534 & 0.3210 & 0.3611 & 1 & \\
\hline D_B & 0.2058 & 0.8403 & 0.0352 & -0.0744 & -0.0886 & -0.0099 & -0.2842 & -0.2290 & -0.3371 & 1 \\
\hline
\end{tabular}

\section{Regression Results}

While focusing on the research objective, Table 3 reports the results of generalized least square regression models to identify the drivers of systemic risk in the banking system of south Asian countries. Column "Variables" represent the variables of study i.e. size, liquidity ratio, leverage, assets growth, return on assets, deposit ratio, and net interest income ratio. Column "All Banks" reports the results of full sample of all banks in south Asian countries and column Pakistan, India, and Bangladesh reports the regression results i.e. co-efficient of the variables and p-value in parenthesis of banks in Pakistan, India and Bangladesh respectively. We estimate the panel regression models but Hausmann (1978) test suggested that the random effect is suitable for banks of Bangladesh and fixed effect model is appropriate for banks of Pakistan and India. Afterward, diagnostic tests highlight the problem of hetroscadasticity and cross-sectional dependence for banks of Pakistan and India, which forced to use generalized least square approach for estimation of research models.

Table 3. Determinants of Commercial Banks in South Asian Countries

\begin{tabular}{|c|c|c|c|c|}
\hline \multirow{2}{*}{ Variables } & All Banks & Pakistan & India & Bangladesh \\
\hline & \multicolumn{4}{|c|}{ Coefficient (P-Value) } \\
\hline Intercept & $-0.0567 * * *(0.000)$ & $-0.1032 * * *(0.000)$ & $-0.0414 * *(0.019)$ & $-0.0754 * *(0.036)$ \\
\hline Size & $0.0014 * *(0.028)$ & $0.0041 * * *(0.000)$ & $0.0009 * *(0.031)$ & $0.0019 * *(0.028)$ \\
\hline Liquidity & $-0.0562 * * *(0.000)$ & $-0.0356 * *(0.024)$ & $-0.0837 * * *(0.004)$ & $0.0227 * *(0.045)$ \\
\hline Leverage & $-0.00002(0.298)$ & $-0.00002(0.359)$ & $-0.0007 *(0.091)$ & $-0.0006(0.188)$ \\
\hline Asset Growth & $-0.0000(0.586)$ & $0.0003(0.257)$ & $-0.0000(0.496)$ & $-0.0093(0.107)$ \\
\hline Return on Assets & $0.0610(0.227)$ & $0.1317 *(0.070)$ & $-0.0621(0.387)$ & $0.4011(0.423)$ \\
\hline Deposit Ratio & $0.0048(0.419)$ & $-0.0018(0.889)$ & $0.0714 *(0.090)$ & $-0.0032(0.781)$ \\
\hline Interest Income & $0.0057 * *(0.019)$ & $-.0009 *(0.072)$ & $-0.0551 *(0.063)$ & $0.0144 * *(0.025)$ \\
\hline D_I & $-0.0075 * * *(0.000)$ & & & \\
\hline D_B & $0.0001(0.991)$ & & & \\
\hline R-Square & 0.2076 & 0.1704 & 0.2607 & 0.1741 \\
\hline F-Statistics & $16.35 * * *(0.000)$ & $17.54 * * *(0.000)$ & $8.61 * * *(0.000)$ & $14.75 * * *(0.000)$ \\
\hline
\end{tabular}

\section{Dependent Variable: Marginal Expected Shortfall}

Size has a significant positive co-efficient for banks of all countries and individually for all countries i-e Pakistan, India and Bangladesh. It shows that large banks contribute less to infect other banks to indulge in financial crisis. It observed from macro percpective that banking system is more vulnerable if it more heavily composed of small banks. Conversely, banking system is considered as more stable if it contains high number of large banks. These results are contradictory with the findings of European banks Haq and Heaney (2012), Black et al. (2013) and Varotto and Zhao (2014). Based on this result, devising policies for controlling of bank size may deployed to reduce the systemic risk. This is contradiction of "Too Big To Fail" arguments. 
It may be the reason that banking policy makers take corrective action against large banks because financial crisis largely hit the large banks.

In Table 3, liquidity has a significant adverse effect on the systemic risk of banks in all countries, Pakistan, and India as well. It shows that the highly liquid banks contribute greater for the systemic risk of the banking system. It may be the reason that banks with greater investment in short lived asset likely to indulge in risk-taking activities and have low NPV project. It results of high contribution in the systemic risk of the banking system. Whereas, bank's liquidity in Bangladesh have positive influence on the systemic risk. It might be the justification that banking policy maker may consider the financial crisis and take corrective action to reduce the negative effect of liquidity on the systemic risk of banking system in Bangladesh.

Our results for leverage, assets growth, return on assets and deposit ratio have insignificant/little effect on the systemic risk of the banking system. Whereas, interest income has mixed effect on the systemic risk. Interest income have significant positive effect on the bank systemic risk in sample of south Asian banks and Bangladesh. However, interest income has adverse effect on the systemic risk in Pakistan and India. It implies that the higher the reliance of a bank on interest income more likely to contribute less in the systemic risk of the banking system in Bangladesh. Moreover, Indian banks dummy have a significant positive impact on the bank systemic risk. It shows that Indian banks contribute higher in the systemic risk of banking system among south Asian countries.

\section{Conclusion}

This study designs to examine the determinants (size, liquidity ratio, leverage ratio, deposit ratio, asset growth, net interest income ratio and return on asset ratio) of bank's systemic risk in south Asian countries. In particular, why some banks contribute higher for the systemic risk of the banking system than their counterparts. The findings demonstrate that larger banks reduce the systemic risk of the banks, while, liquid banks enhance the systemic risk of the banking system. Moreover, the banks with greater reliance on the deposits, net interest income and high return on asset reduce the systemic risk contribution by banks.

The finding of this study put note for policymakers and regulatory authorities of the banking system to consider multiple factors while assessing the systemic risk contribution of individual banks. Therefore, macro-prudential regulation of banking system needs to be devised while assessing the systemic risk of bank for smooth banking operation in a country, like consider bank size, liquidity requirement, and asset structure to mitigate the systemic risk contribution. The study would helpful for regulators and policymakers, supervising financial institutions and banks to examine the indicators which likely to contribute in systemic risk of financial system and give attention to systemically important banks. Finally, regulatory authorities and policymakers must impellent policies for future to avoid systemic risk. Furthermore, study may provide the justification to design the banking system in compliance with the findings of this study to reduce the systemic risk contribution of the banking system.

\section{References}

Acharya, V., Engle, R., \& Richardson, M. (2012). Capital shortfall: A new approach to ranking and regulating systemic risks. The American Economic Review, 102(3), 59-64

Acharya, V. V., Pedersen, L. H., Philippon, T., \& Richardson, M. (2017). Measuring systemic risk. The Review of Financial Studies, 30(1), 2-47.

Acharya, V.V. and Steffen, S. (2012), "Analyzing Systemic Risk of the European Banking Sector," NYU Stern Working Paper.in Handbook on Systemic Risk, edit. J.-P- Fouque and J. Langsam. Cambridge University Press 
Adrian, T. \& Brunnermeier, M. K. (2016). CoVaR. American Economic Review, 106(7), 17051741.

Bori, N., Caccavaio, Marianna, Di Giorgio, Giorgio, Sorrentino, A., 2012. Systemic risk in the European banking sector, CASMEF Working Paper Series, Rome.

Brownlees, C.T., 2011. On the Relation between Firm Characteristics and Volatility Dynamics with an Application to the 2007-2009 Financial Crisis. NYU

Brownlees, C.T. And Engle, R.F. (2012), "Volatility, Correlation and Tails for Systemic Risk Measurement,"NYU Stern Working Paper.

Elsinger, H., Lehar, A., \& Summer, M. (2006). Systemically important banks: an analysis for the European banking system. International Economics and Economic Policy,(1), 73-89.

Engle, R., Jondeau, E., \&Rockinger, M. (2015). Systemic risk in Europe. Review of Finance, 19(1), 145-190.

Galati, G., \& Moessner, R. (2013). Macro prudential policy-a literature review. Journal of Economic Surveys, 27(5), 846-878.

Gauthier, C., Lehar, A., \&Souissi, M. (2012). Macro prudential capital requirements and systemic risk. Journal of Financial Intermediation, 21(4), 594-618.

Hautsch, N., Schaumburg, J., Schienle, M., 2014. Forecasting systemic effecting financial networks. International Journal of Forecasting 30 (3), 781-794.

Koopman, S. J., Lucas, A., \&Schwaab, B. (2010). Macro, industry and frailty effects in defaults: the 2008 credit crisis in perspective (No. 10-004/2). Tinbergen Institute Discussion Paper.

Lehar, A. (2005). Measuring systemic risk: A risk management approach. Journal of Banking and Finance, 29, 2577-603.

Matar, M.(2003). Recent Trends in Credit Analysis Methods, tools and general uses(p. 28). Amman, Jordan: Dar Wael Publishing.

Mills, J. (2018). Financial Institutions and Systemic Risk: The Case of Bank of America 20062017.

Segoviano, A., \& Goodhart, C. (2009). Banking stability measures. Financial Markets Group Working Paper, London School of Economics and Political Science.

Vallascas, F., Keasey, K., 2012. Bank resilience to systemic shocks and the stability of banking systems: Small is beautiful. Journal of International Money and Finance 31 (6). 